\title{
Electrical Properties of Cu0-Doped PZT-PZN-PMnN Piezoelectric Ceramics Sintered at Low Temperature
}

\author{
Phan Dinh Gio ${ }^{1 *}$, Le Dai Vuong1,2, Ho Thi Thanh Hoa ${ }^{1}$ \\ ${ }^{1}$ Department of Physics, College of Sciences, Huế University, Huế, Vietnam \\ ${ }^{2}$ Faculty of Chemical and Environmental Engineering, Huế Industry College, Huế, Vietnam \\ Email: *pdg55@yahoo.com, ledaivuongqb@gmail.com
}

Received 8 September 2014; revised 1 October 2014; accepted 24 October 2014

Copyright (C) 2014 by authors and Scientific Research Publishing Inc.

This work is licensed under the Creative Commons Attribution International License (CC BY). http://creativecommons.org/licenses/by/4.0/

c) (i) Open Access

\section{Abstract}

The 0.8Pb( $\left.\mathrm{Zr}_{0.48} \mathrm{Ti}_{0.52}\right) \mathrm{O}_{3}-0.125 \mathrm{~Pb}\left(\mathrm{Zn}_{1 / 3} \mathrm{Nb}_{2 / 3}\right) \mathrm{O}_{3}-0.075 \mathrm{~Pb}\left(\mathrm{Mn}_{1 / 3} \mathrm{Nb}_{2 / 3}\right) \mathrm{O}_{3}(\mathrm{PZT}-\mathrm{PZN}-\mathrm{PMnN})+\mathrm{x}$ wt\% CuO piezoelectric ceramics, where $x=0.0,0.05,0.075,0.10,0.125,0.150$, and 0.175 , have been fabricated by the conventional solid-state reaction method and the B-site Oxide mixing technique (BO). The effect of CuO on the sinterability, structure, and electrical properties of PZT-PZN-PMnN ceramics was systematically studied. The $\mathrm{CuO}$ addition significantly reduced the sintering temperature of the ceramics from $1150^{\circ} \mathrm{C}$ to $850^{\circ} \mathrm{C}$. Experimental results showed that with the doping of $\mathrm{CuO}$, all the ceramics could be well sintered and exhibit a dense, pure perovskite structure. The specimen containing $0.125 \mathrm{wt} \% \mathrm{CuO}$ sintered at $850^{\circ} \mathrm{C}$ showed the good electrical properties: the density of $7.91 \mathrm{~g} / \mathrm{cm}^{3}$; the electromechanical coupling factor, $k_{\mathrm{p}}=0.55$ and $\mathrm{k}_{\mathrm{t}}=0.46$; the dielectric constant, $\varepsilon=1179$; the dielectric loss $(\tan \delta)$ of 0.006 ; the mechanical quality factor $\left(\mathrm{Q}_{\mathrm{m}}\right)$ of 1174 ; the piezoelectric constant $\left(d_{31}\right)$ of $112 \mathrm{pC} / \mathrm{N}$.

\section{Keywords}

Crystal Structure, Dielectric, Piezoelectric Constant, Mechanical Quality Factor

\section{Introduction}

In recent years, many material scientists are interested in research and application of multi-component piezoelectric ceramics combine PZT with relaxor ferroelectrics, such as $\mathrm{Pb}\left(\mathrm{Zr}_{0.48} \mathrm{Ti}_{0.52}\right) \mathrm{O}_{3}-\mathrm{Pb}\left(\mathrm{Zn}_{1 / 3} \mathrm{Nb}_{2 / 3}\right) \mathrm{O}_{3}(\mathrm{PZT}-$ $\mathrm{PZN}), \quad \mathrm{Pb}\left(\mathrm{Zr}_{0.48} \mathrm{Ti}_{0.52}\right) \mathrm{O}_{3}-\mathrm{Pb}\left(\mathrm{Mg}_{1 / 3} \mathrm{Nb}_{2 / 3}\right) \mathrm{O}_{3}$ (PZT-PMN), $\mathrm{Pb}\left(\mathrm{Zr}_{0.48} \mathrm{Ti}_{0.52}\right) \mathrm{O}_{3}-\mathrm{Pb}\left(\mathrm{Zn}_{1 / 3} \mathrm{Nb}_{2 / 3}\right) \mathrm{O}_{3}-\mathrm{Pb}\left(\mathrm{Mn}_{1 / 3} \mathrm{Nb}_{2 / 3}\right) \mathrm{O}_{3}$

"Corresponding author.

How to cite this paper: Gio, P.D., Vuong, L.D. and Hoa, H.T.T. (2014) Electrical Properties of CuO-Doped PZT-PZN-PMnN Piezoelectric Ceramics Sintered at Low Temperature. Journal of Materials Science and Chemical Engineering, 2, 20-27. http://dx.doi.org/10.4236/msce.2014.211004 
(PZT-PZN-PMnN), etc., due to their excellent piezoelectric properties and many applications in piezoelectric actuators and transformers [1]-[6]. These ceramics often have large dielectric constant $\varepsilon$, high mechanical quality factor $\left(\mathrm{Q}_{\mathrm{m}}\right)$, high electromechanical coupling factor $\left(\mathrm{k}_{\mathrm{p}}\right)$, high Curie temperature and low dielectric loss factor $(\tan \delta)$. However, the sintering temperature of the ceramics is quite high $\left(>1150^{\circ} \mathrm{C}\right)$, which leads evaporation of $\mathrm{PbO}$ during sintering process, resulting in reducing properties of ceramic compositions and environmental pollution. Therefore, lowering sintering temperature of PZT based ceramics is very necessary.

There are many methods to lower the sintering temperature, however, the most common and effective method to reduce the sintering temperature of PZT based ceramics is to add the low-temperature melting oxides or compounds for liquid phase sintering at a low temperature. Many researchers have successfully decreased the sintering temperature of PZT based ceramics by using various additives such as $\mathrm{B}_{2} \mathrm{O}_{3}, \mathrm{Bi}_{2} \mathrm{O}_{3}, \mathrm{Li}_{2} \mathrm{CO}_{3}, \mathrm{BiFeO}_{3}$, $\mathrm{CuO}, \mathrm{CuO}+\mathrm{Bi}_{2} \mathrm{O}_{3}$, etc. [7]-[14].

In some cases, these additives can facilitate lower the sintering temperature, but decrease simultaneously the piezoelectric properties of ceramics due to the formation of piezoelectrically inactive phases in the grain boundary regions. Therefore, the research and fabrication ceramics sintered at low temperature, while improving or not reducing the piezoelectric properties of ceramics system are very important.

Recently, we studied the effect of $\mathrm{Li}_{2} \mathrm{CO}_{3}$ addition on the sintering behaviour and physical properties of PZTPZN-PMnN ceramics. We decreased the sintering temperature of ceramics from $1150^{\circ} \mathrm{C}$ to $930^{\circ} \mathrm{C}$ and maintained good electrical properties: the electromechanical coupling factor $\mathrm{k}_{\mathrm{p}}=0.64$, the dielectric constant $\varepsilon=$ 1320 , the dielectric loss $(\tan \delta)$ of 0.005 , the mechanical quality factor $\left(Q_{m}\right)$ of 1150 , the piezoelectric constant $\left(\mathrm{d}_{31}\right)$ of $145 \mathrm{pC} / \mathrm{N}$, and the remanent polarization $\left(\mathrm{P}_{\mathrm{r}}\right)$ of $30.5 \mu \mathrm{C} / \mathrm{cm}^{2}[7]$.

In this work, we present some research results on the effect of $\mathrm{CuO}$ on the sinterability, structure, and electrical properties of PZT-PZN-PMnN ceramics.

\section{Experimental Procedure}

The general formula of the studied material was $0.8 \mathrm{~Pb}\left(\mathrm{Zr}_{0.48} \mathrm{Ti}_{0.52}\right) \mathrm{O}_{3}-0.125 \mathrm{~Pb}\left(\mathrm{Zn}_{1 / 3} \mathrm{Nb}_{2 / 3}\right) \mathrm{O}_{3}-0.075 \mathrm{~Pb}\left(\mathrm{Mn}_{1 / 3} \mathrm{Nb}_{2 / 3}\right) \mathrm{O}_{3}$ $(\mathrm{PZT}-\mathrm{PZN}-\mathrm{PMnN})+\mathrm{x}$ wt $\% \mathrm{CuO}$, where $\mathrm{x}=0.0,0.05,0.075,0.10,0.125,0.150$, and 0.175 . Reagent grade oxide powders of $\mathrm{PbO}, \mathrm{ZnO}, \mathrm{MnO}_{2}, \mathrm{Nb}_{2} \mathrm{O}_{5}, \mathrm{ZrO}_{2}, \mathrm{TiO}_{2}$ and $\mathrm{CuO}$ (purity $\geq 99 \%$ ) were used as starting materials.

The PZN based ceramic materials with the a pure perovskite structure are very difficult to prepare by conventional ceramic processing, because of the high polarizability of $\mathrm{Pb}^{2+}$ and its interaction with $\mathrm{Zn}^{2+}$ cations, resulting the formation of the pyrochore phase and they will be detrimental to the physical properties of lead based ferroelectric ceramics [15]. Therefore, in this work, we combined the conventional solid-state reaction method and the B-site Oxide mixing technique (BO) for fabricate ceramic samples. Firstly, the mixture of $\left(\mathrm{Zn}_{0.125} \mathrm{Mn}_{0.075}\right) \mathrm{Nb}_{0.4}\left[\left(\mathrm{Zr}_{0.48} \mathrm{Ti}_{0.52}\right)_{2.4}\right] \mathrm{O}_{6}$ (BO) were prepared by reactions of $\mathrm{ZnO}, \mathrm{MnO}_{2}, \mathrm{Nb}_{2} \mathrm{O}_{5}, \mathrm{ZrO}_{2}$ and $\mathrm{TiO}{ }_{2}$ at temperature $1100^{\circ} \mathrm{C}$ for $2 \mathrm{~h}$. Then, the powders of $\mathrm{BO}$ and $\mathrm{PbO}$ were weighed and milled for $8 \mathrm{~h}$. The powders were calcined at temperature $850^{\circ} \mathrm{C}$ for $2 \mathrm{~h}$, producing the PZT-PZN-PMnN compound. Thereafter CuO were mixed with the calcined PZT-PZN-PMnN powder, and powders milled for $16 \mathrm{~h}$. The ground materials were pressed into disk $12 \mathrm{~mm}$ in diameter and $1.5 \mathrm{~mm}$ in thick under $100 \mathrm{MPa}$. These pellets were coated with $\mathrm{PbZrO}_{3}$ powder then were sintered in a sealed alumina crucible at the temperature of $800^{\circ} \mathrm{C}, 830^{\circ} \mathrm{C}, 850^{\circ} \mathrm{C}$, and $870^{\circ} \mathrm{C}$ for $4 \mathrm{~h}$.

The crystal structure of the sintered samples was examined by X-ray diffraction (XRD, D8 ADVANCE). The microstructure of the samples was examined by using a scanning electron microscope (SEM) (Hitachi S-4800). The densities of samples were measured by Archimedes method. The ceramic samples were polled in a silicone oil bath at $120^{\circ} \mathrm{C}$ by applying dc field of $30 \mathrm{kV} / \mathrm{cm}$ for $20 \mathrm{~min}$ then cooling down to room temperature under the same electric field. They were aged for $24 \mathrm{~h}$ prior to testing. The piezoelectric properties were determined by the resonance and antiresonance frequencies using an impedance analyzer (HP 4193A and RLC HIOKI 3532). Temperature dependence of dielectric constant was determined using RLC HIOKI 3532 with automatic programming; temperature of the samples was measured using Digital Multimeter 7562. The ferroelectric property was measured by Sawyer-Tower method.

\section{Results and Discussion}

Figure 1 shows the densities as a function of sintering temperature for PZT-PZN-PMnN ceramics with various 


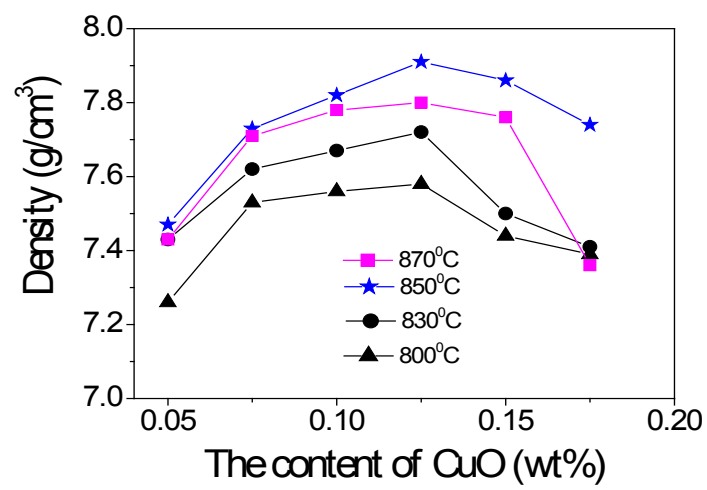

Figure 1. The density of PZT-PZN-PMnN ceramics with different amounts of $\mathrm{CuO}$ additive sintered at different temperatures: $800^{\circ} \mathrm{C}$, $830^{\circ} \mathrm{C}, 850^{\circ} \mathrm{C}$, and $870^{\circ} \mathrm{C}$.

$\mathrm{CuO}$ additions. With increasing of sintering temperature and $\mathrm{CuO}$ content, the density increases and reaches the maximum value $\left(7.91 \mathrm{~g} / \mathrm{cm}^{3}\right)$ at $850^{\circ} \mathrm{C}$ sintering temperature and at $0.125 \mathrm{wt} \% \mathrm{CuO}$ content, then decreases. In our previous work [7], the sintering temperature of undoped PZT-PZN-PMnN ceramics was as high as $1150^{\circ} \mathrm{C}$ (the density of $7.82 \mathrm{~g} / \mathrm{cm}^{3}$ ). Thus, the addition of $\mathrm{CuO}$ improved the sinterability, reduced the sintering temperature of $300^{\circ} \mathrm{C}$ compared with pure samples and increasing density of the ceramic samples. The above results consistent with the work of the authors $\mathrm{Kim}$ and co-worker studied the effect of $\mathrm{CuO}$ on structure and electrical properties of $0.4 \mathrm{~Pb}\left(\mathrm{Mg}_{1 / 3} \mathrm{Nb}_{2 / 3}\right) \mathrm{O}_{3}-0.25 \mathrm{PbZrO}_{3}-0.35 \mathrm{PbTiO}_{3}$ ceramic system [16].

Figure 2 shows the SEM images of the PZT-PZN-PMnN $+\mathrm{x} w \mathrm{wt} \% \mathrm{CuO}$ ceramics sintered at $850^{\circ} \mathrm{C}:$ (a) $\mathrm{x}=$ 0.0 , (b) $x=0.05$, (c) $x=0.075$, (d) $x=0.10$, (e) $x=0.125$ and (g) $x=0.150$. Figure 2(a) shows the microstructure of discrete grains, porous, not sintered materials. However, the microstructure of samples becomes denser and grain size increases as the $\mathrm{CuO}$ sintering aid is increased (Figures 2(b)-(e)). A homogeneous microstructure developed for the sample with $0.125 \mathrm{wt} \% \mathrm{CuO}$ added (Figure 2(e)). However, Figure 2(g) also shows that further increasing the $\mathrm{CuO}$ content to $0.125 \mathrm{wt} \%$ gives rise to an abnormal grain boundary, porous appeared, the average grain size reduces. Such with the $0.125 \mathrm{wt} \% \mathrm{CuO}$-added sample, the highly dense and homogeneous microstructure was obtained, which may expect improved properties of ceramics.

The lowering of the sintering temperature and grain growth with $\mathrm{CuO}$ addition can be explained by liquid phase sintering. The phase diagram of Hitoshi Kitaguchi [17] has shown that $\mathrm{CuO}$ and $\mathrm{PbO}$ form the liquid phase at point eutectic $789^{\circ} \mathrm{C}$. So when $\mathrm{CuO}$ doped in PZT-PZN-PMnN ceramics, $\mathrm{CuO}$ reacted with $\mathrm{PbO}$ and formed a liquid phase during the sintering, which assisted the densification of the specimens and increasing grain size. The second phase occurs at grain boundaries related to the limited solubility of $\mathrm{CuO}$.

Figure 3 shows the XRD patterns of the PZT-PZN-PMnN $+\mathrm{x} \mathrm{wt} \% \mathrm{CuO}$ ceramic samples sintered at $850^{\circ} \mathrm{C}$ for $4 \mathrm{~h}$. It can be seen that all samples exhibit a perovskite structure, and not detect a second phase until $\mathrm{x}=$ 0.125 . However, when the $\mathrm{CuO}$ content increases over $0.125 \mathrm{wt} \%$, second phase peak was observed. Crystal structure of the samples is modified significantly by $\mathrm{CuO}$ additions. For the pure sample $(\mathrm{x}=0.0)$, the rhombohedral structure developed. All the samples with the addition of $\mathrm{CuO}$ had a tetragonal structure as indicated by the splitting of $(002)$ and $(200)$ peaks at $2 \theta \approx 44^{\circ}$. However, phase transition did not appear. This result suggests that $\mathrm{Cu}^{2+}$ ions are substituted for $\mathrm{B}$-site of perovskite structure $\mathrm{ABO}_{3}$ which lead to the distortion of crystal lattice. The results are consistent with several published works [18]-[21].

Figure 4 shows temperature dependence of dielectric constant $\varepsilon$ and dielectric loss $\tan \delta$ as a function of $\mathrm{CuO}$ content. With increasing $\mathrm{CuO}$ doping, Curie temperature $\left(\mathrm{T}_{\mathrm{c}}\right)$ of PZT-PZN-PMnN ceramics slight decreases. The composition with $0.125 \mathrm{wt} \% \mathrm{CuO}$ content shows highest peak dielectric constants $(12,000)$, which appears at about $266^{\circ} \mathrm{C}$.

Figure 5 shows temperature dependence of dielectric constant $\varepsilon$ of $0.125 \mathrm{wt} \% \mathrm{CuO}$-doped ceramic sample measured at frequency of $1 \mathrm{kHz}, 10 \mathrm{kHz}, 100 \mathrm{kHz}$ and $1 \mathrm{MHz}$. It can be seen that the shape of the $\varepsilon(\mathrm{T})$ peaks are broad, which is typical of a case diffuse transition with frequency dispersion. When the measured frequency increases, the maximum of $\varepsilon_{\max }$ decreases and shifts toward higher temperatures while dielectric loss increases near the Curie point, which is typical of a relaxor material [1] [7]. 

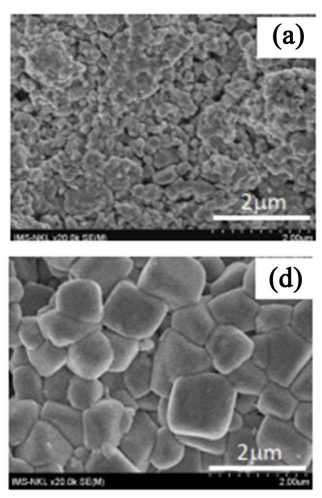

(d)
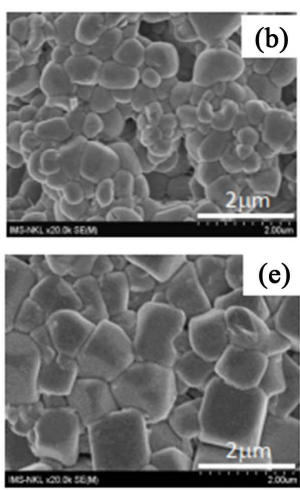
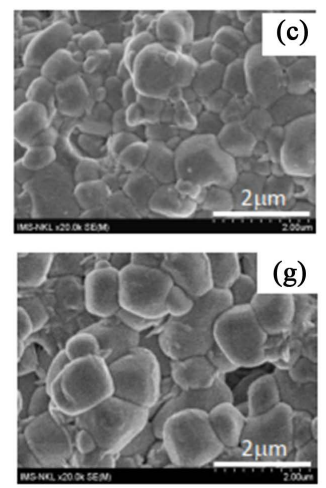

Figure 2. SEM images of PZT-PZN-PMnN with different amounts of $\mathrm{CuO}$ additive sintered at $850^{\circ} \mathrm{C}$ : (a) $\mathrm{x}=0.0$; (b) $\mathrm{x}=0.05$; (c) $\mathrm{x}=0.075$; (d) $\mathrm{x}=0.10$; (e) $\mathrm{x}=0.125 ;(\mathrm{g}) \mathrm{x}=0.150$.

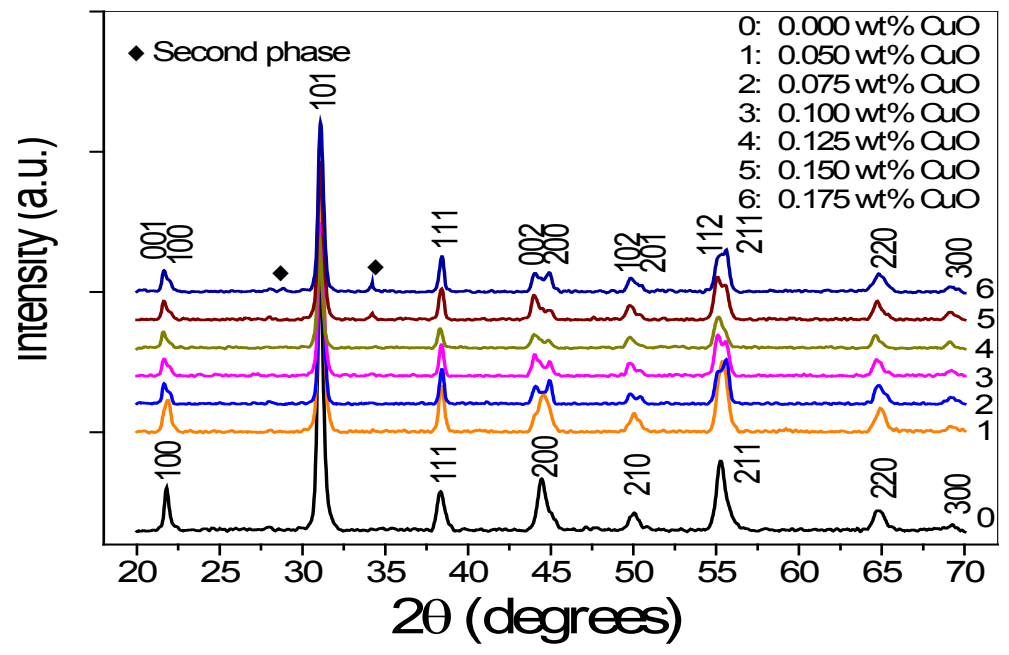

Figure 3. X-ray diffraction patterns of the PZT-PZN-PMnN with different amounts of $\mathrm{CuO}$ additive sintered at $850^{\circ} \mathrm{C}$ : (0) $\mathrm{x}=0.0$; (1) $\mathrm{x}=0.05$; (2) $\mathrm{x}=$ 0.075 ; (3) $\mathrm{x}=0.10$; (4) $\mathrm{x}=0.125 ;(5) \mathrm{x}=0.150 ;(6) \mathrm{x}=0.175$.

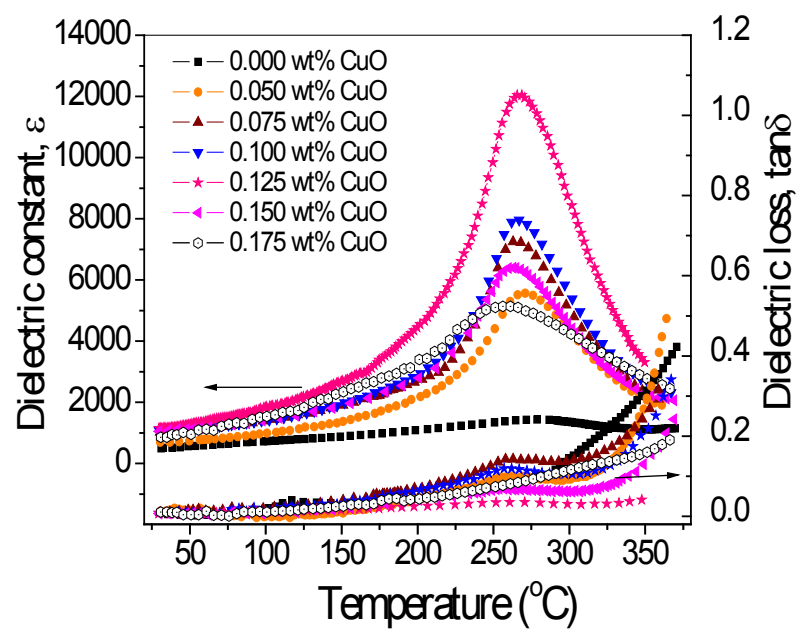

Figure 4. Temperature dependence of dielectric constant $\varepsilon$ and dielectric loss $\tan \delta$ of the PZT-PZN-PMnN ceramics with different amounts of $\mathrm{CuO}$ additive sintered at $850^{\circ} \mathrm{C}$. 


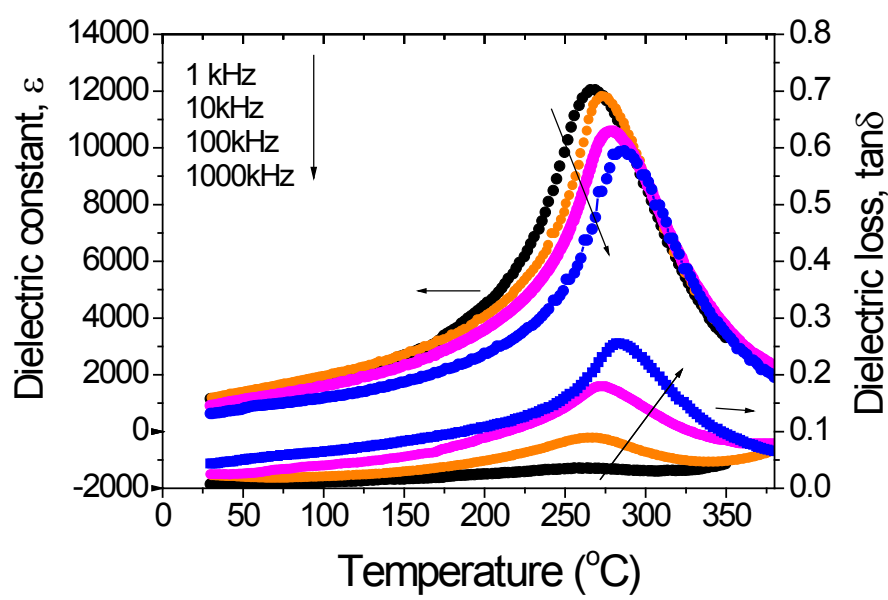

Figure 5. Temperature dependence of dielectric constant $\varepsilon$ of $0.125 \mathrm{wt} \%$ $\mathrm{CuO}$-doped sample measured at different frequencies: $1 \mathrm{kHz}, 10 \mathrm{kHz}$, $100 \mathrm{kHz}$ and $1 \mathrm{MHz}$.

To determine piezoelectric properties of ceramics, resonant vibration spectra of samples were measured at room temperature (Figure 6). From these resonant spectra, piezoelectric parameters of samples were determined.

Figure 7 and Figure 8 show the electromechanical coupling factor $\left(\mathrm{k}_{\mathrm{p}}, \mathrm{k}_{\mathrm{t}}\right)$, the piezoelectric constant $\left(\mathrm{d}_{31}\right)$, the mechanical quality factor $\left(\mathrm{Q}_{\mathrm{m}}\right)$, the dielectric constant $(\varepsilon)$ and dielectric loss $(\tan \delta)$ change as a function of the $\mathrm{CuO}$ content. When the $\mathrm{CuO}$ content is lower than $0.125 \mathrm{wt} \%$, the values of $\mathrm{k}_{\mathrm{p}}, \mathrm{k}_{\mathrm{t}}, \mathrm{d}_{31}, \varepsilon$ and $\mathrm{Q}_{\mathrm{m}}$ are rapidly increase with increasing content of $\mathrm{CuO}$, while the dielectric loss tan $\delta$ are strong decrease. The largest values for $\mathrm{k}_{\mathrm{p}}$ of $0.55, \mathrm{k}_{\mathrm{t}}$ of $0.46, \mathrm{~d}_{31}$ of $112 \mathrm{pC} / \mathrm{N}, \varepsilon$ of $1179, \mathrm{Q}_{\mathrm{m}}$ of 1174 and minimum value of the dielectric loss $\tan \delta$ is 0.006 were obtained at $x=0.125$. These are probably related to characteristics of the density and the increasing grain size. During sintering, the presence of liquid phase enhances the density and grain size, which leads to the decrease of the energy loss and improvement of the electrical properties. Chao et al. [21] investigated CuOdoped PZT-PMN-PZN ceramics with compositions close to the morphotropic phase boundary (MPB) sintered at $920^{\circ} \mathrm{C}$. The optimized results of $\mathrm{k}_{\mathrm{p}}(0.53), \varepsilon(982)$ and $\mathrm{Q}_{\mathrm{m}}(1645)$ were obtained at $0.2 \mathrm{wt} \% \mathrm{CuO}$.

Nam et al. [14] also showed that $\mathrm{CuO}$ could increase the piezoelectric properties and reducing the sintering temperature of $\mathrm{MnO}_{2}$-doped $0.75 \mathrm{~Pb}\left(\mathrm{Zr}_{0.47} \mathrm{Ti}_{0.53}\right) \mathrm{O}_{3}-0.25 \mathrm{~Pb}\left(\mathrm{Zn}_{1 / 3} \mathrm{Nb}_{2 / 3}\right) \mathrm{O}_{3}$ ceramics from $930^{\circ} \mathrm{C}$ down to $850^{\circ} \mathrm{C}$ The optimized values for $\mathrm{k}_{\mathrm{p}}$ of $0.50, \mathrm{Q}_{\mathrm{m}}$ of 1000 were obtained at at $0.5 \mathrm{wt} \% \mathrm{CuO}$. The ceramic samples have a lower $\mathrm{k}_{\mathrm{p}}$ and $\mathrm{Q}_{\mathrm{m}}$ values than that of our ceramic samples. Accordingly, compared with the research results of $\mathrm{F}$. Gao and co-workers on the PZT-PZN-PMnN ceramics [3], in our work with a small amount of $\mathrm{CuO}$ was added to PZT-PZN-PMnN ceramics reduced the sintering temperature of $300^{\circ} \mathrm{C}$, with the retention of good piezoelectric properties.

Figure 9 shows the shape of feroelectric hysteresis loops of the samples PZT-PZN-PMnN $+\mathrm{x} w \mathrm{wt} \% \mathrm{CuO}$ measured at room temperature. From the shape of these loops, the remanent polarization $\left(P_{r}\right)$ and the coercive field $\left(E_{C}\right)$ were determined, as shown in Figure 10. With increasing of $\mathrm{CuO}$ content, a sharp increases in $\mathrm{P}_{\mathrm{r}}$ was observed for samples until $\mathrm{x}=0.125$, reaches the highest value $\left(16 \mu \mathrm{C} / \mathrm{cm}^{2}\right)$ at $\mathrm{x}=0.125$, and then decreases, while the coercive field $\mathrm{E}_{\mathrm{C}}$ strong decreases and reaches smallest value $(4.5 \mathrm{kV} / \mathrm{cm})$ at $\mathrm{x}=0.125$. These results are in good agreement with the studied dielectric and piezoelectric properties of the ceramic samples.

\section{Conclusion}

The effect of $\mathrm{CuO}$ addition on the sintering behavior and physical properties of $0.8 \mathrm{~Pb}\left(\mathrm{Zr}_{0.48} \mathrm{Ti}_{0.52}\right) \mathrm{O}_{3^{-}}$ $0.125 \mathrm{~Pb}\left(\mathrm{Zn}_{1 / 3} \mathrm{Nb}_{2 / 3}\right) \mathrm{O}_{3}-0.075 \mathrm{~Pb}\left(\mathrm{Mn}_{1 / 3} \mathrm{Nb}_{2 / 3}\right) \mathrm{O}_{3}+\mathrm{x}$ wt $\% \mathrm{CuO}(\mathrm{x}=0.0 \div 0.175)$ ceramics was investigated. The addition of $\mathrm{CuO}$ improved the sinterability of the samples and caused an increase in the density and grain size at low sintering temperature $\left(850^{\circ} \mathrm{C}\right)$. All samples have pure perovskite phase. Crystal structure of the ceramics is modified significantly from rhombohedral structure to tetragonal structure by $\mathrm{CuO}$ additions. At the $\mathrm{CuO}$ content of $0.125 \mathrm{wt} \%$, physical properties of ceramics are best: the density of $7.91 \mathrm{~g} / \mathrm{cm}^{3}$; the electromechanical 


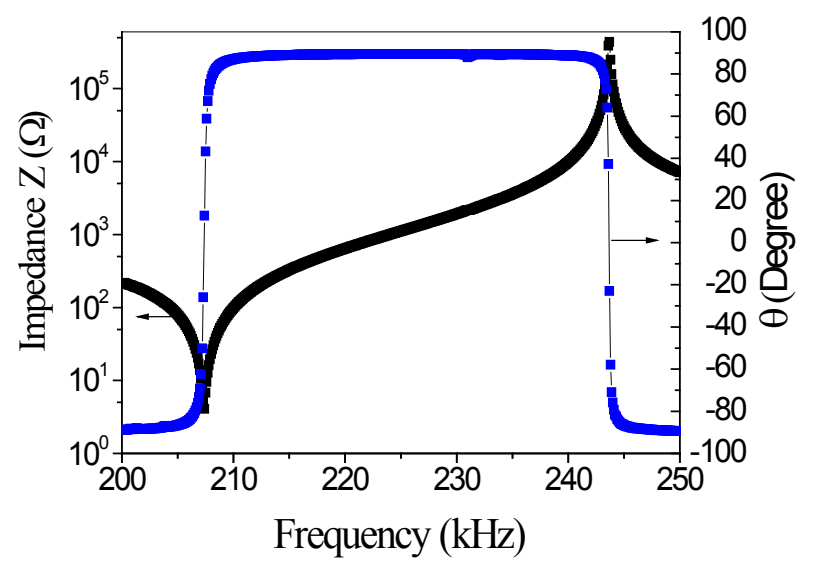

Figure 6. Spectrum of radial resonance of PZT-PZN-PMnN + $0.125 \mathrm{wt} \% \mathrm{CuO}$ ceramic sample sintered at $850^{\circ} \mathrm{C}$.

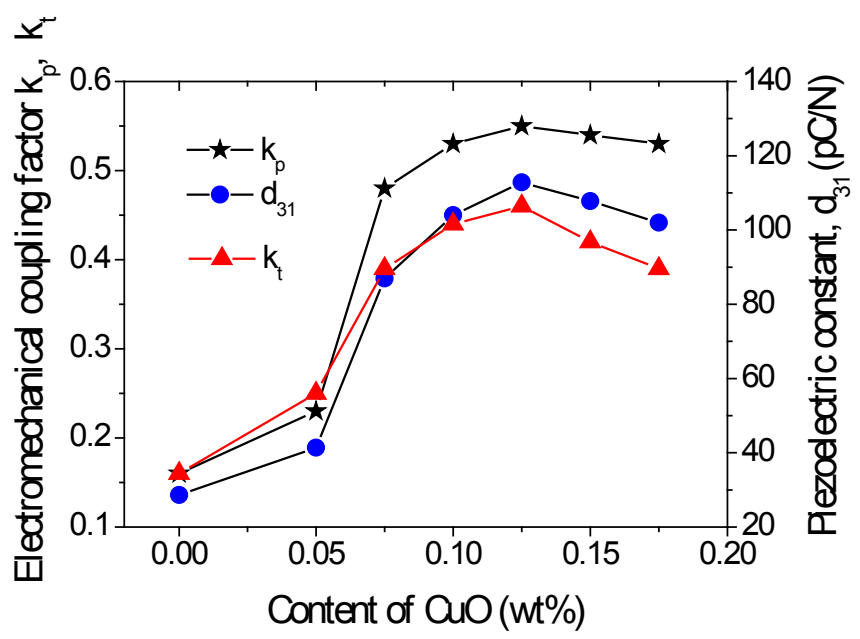

Figure 7. Electromechanical coupling factor $\mathrm{k}_{\mathrm{p}}, \mathrm{k}_{\mathrm{t}}$ and piezoelectric constant $\mathrm{d}_{31}$ of PZT-PZN-PMnN ceramics sintered at $850^{\circ} \mathrm{C}$ as a function of $\mathrm{CuO}$ content.

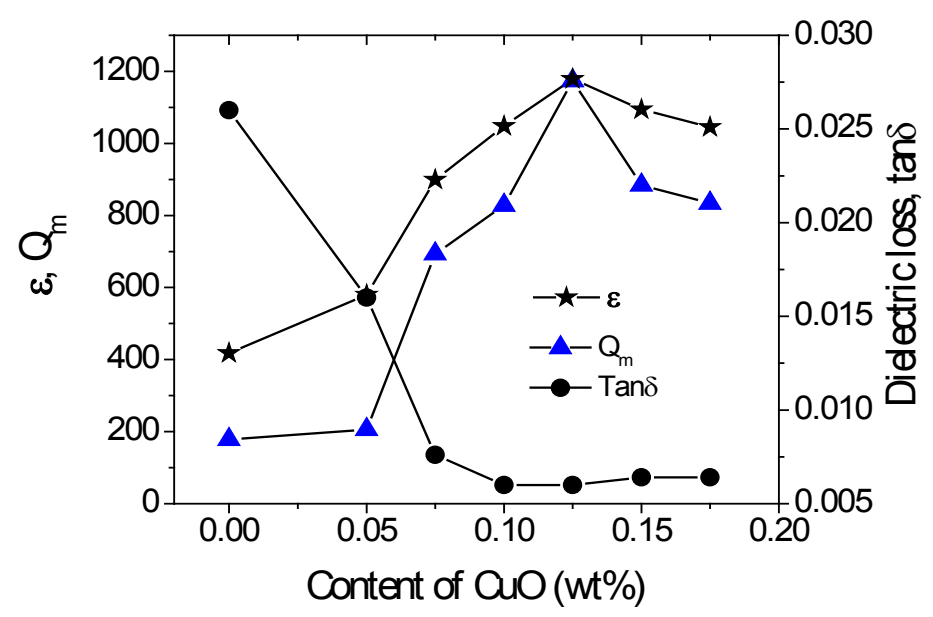

Figure 8. Dielectric constant $\varepsilon$, dielectric loss $\tan \delta$ and mechanical quality factor $\mathrm{Q}_{\mathrm{m}}$ of PZT-PZN-PMnN ceramics sintered at $850^{\circ} \mathrm{C}$ as a function of $\mathrm{CuO}$ content. 


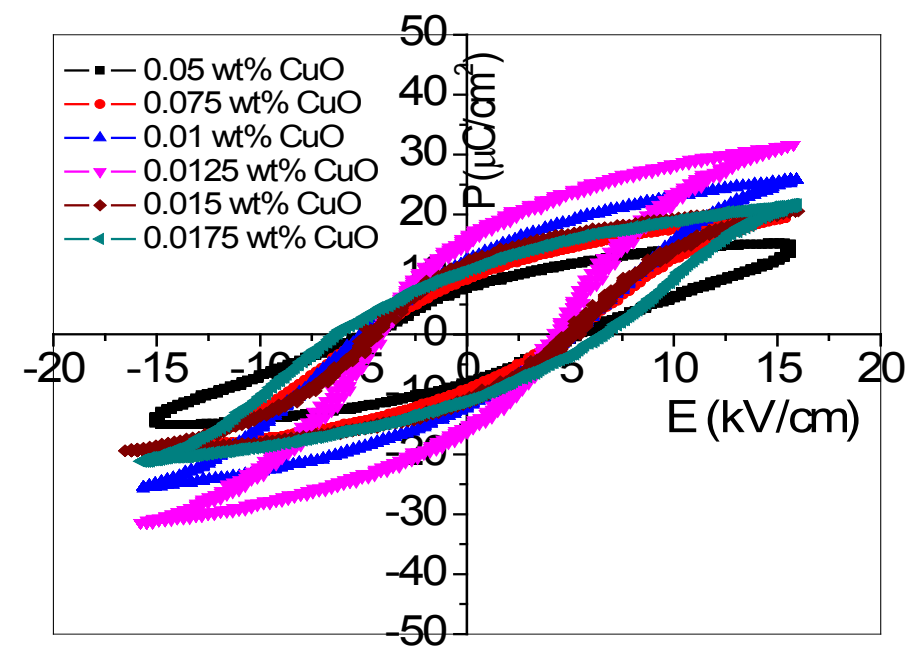

Figure 9. Hysteresis loops of PZT-PZN-PMnN $+\mathrm{x} \mathrm{wt} \% \mathrm{CuO}$ ceramic samples.

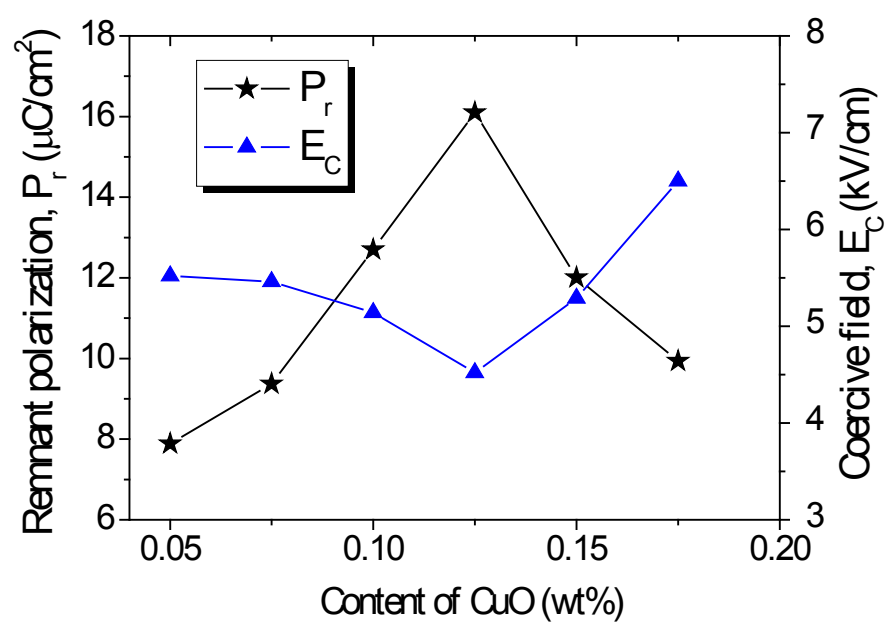

Figure 10. The remnant polarization $\left(\mathrm{P}_{\mathrm{r}}\right)$ and coercive field $\left(\mathrm{E}_{\mathrm{C}}\right)$ as a function of the $\mathrm{CuO}$ content.

coupling factor, $\mathrm{k}_{\mathrm{p}}=0.55$ and $\mathrm{k}_{\mathrm{t}}=0.46$; the dielectric constant, $\varepsilon=1179$; the dielectric loss $(\tan \delta)$ of 0.006 ; the mechanical quality factor $\left(\mathrm{Q}_{\mathrm{m}}\right)$ of 1174 ; the piezoelectric constant $\left(\mathrm{d}_{31}\right)$ of $112 \mathrm{pC} / \mathrm{N}$; the remanent polarization $\left(\mathrm{P}_{\mathrm{r}}\right)$ of $16 \mu \mathrm{C} / \mathrm{cm}^{2}$. The improvement of the electrical properties of the ceramics after adding $\mathrm{CuO}$ is mainly due to the presence of liquid phase in during sintering enhances the density and grain size, which leads to the decrease of the energy loss and improvement of the electrical properties.

\section{References}

[1] Xu, Y. (1991) Ferroelctric Materials and Their Applications. North-Holland, Amsterdam-London-New York-Tokyo.

[2] Hou, Y.D., Zhu, M.K., Tian, C.S. and Yan, H. (2004) Structure and Electrical Properties of PMZN-PZT Quaternary Ceramics for Piezoelectric Transformers. Sensors and Actuators A: Physical, 116, 455-460. http://dx.doi.org/10.1016/j.sna.2004.05.012

[3] Gao, F., Cheng, L., Hong, R., Liu, J., Wang, C. and Tian, C. (2009) Crystal Structure and Piezoelectric Properties of $x \mathrm{~Pb}\left(\mathrm{Mn}_{1 / 3} \mathrm{Nb}_{2 / 3}\right) \mathrm{O}_{3}-(0.2-x) \mathrm{Pb}\left(\mathrm{Zn}_{1 / 3} \mathrm{Nb}_{2 / 3}\right) \mathrm{O}_{3}-0.8 \mathrm{~Pb}\left(\mathrm{Zr}_{0.52} \mathrm{Ti}_{0.48}\right) \mathrm{O}_{3}$ Ceramics. Ceramics International, 35, $1719-1723$. http://dx.doi.org/10.1016/j.ceramint.2008.09.001

[4] Hou, Y.D, Chang, L.M., Zhu, M.K., Song, X.M. and Yan, H. (2007) Effect of $\mathrm{Li}_{2} \mathrm{CO}_{3}$ Addition on the Dielectric and Piezoelectric Responses in the Low-Temperature Sintered 0.5PZN-0.5PZT Systems. Journal of Applied Physics, 102, 
Article ID: 084507. http://dx.doi.org/10.1063/1.2800264

[5] Jin, B.M., Lee, D.S., Kimb, I.W., Kwon, J.H., Lee, J.S., Song, J.S. and Jeong, S.J. (2004) The Additives for Improving Piezoelectric and Ferroelectric Properties of $0.2 \mathrm{~Pb}\left(\mathrm{Mg}_{1 / 3} \mathrm{Nb}_{2 / 3}\right) \mathrm{O}_{3}-0.8\left[\mathrm{PbZrO}_{3}-\mathrm{PbTiO}_{3}\right]$ Ceramics. Ceramics International, 30, 1449-1451. http://dx.doi.org/10.1016/j.ceramint.2003.12.070

[6] Lee, J.S., Choi, M.S., Hung, N.V., Kim, Y.S., Kim, I.W., Park, E.C., Jeong, S.J. and Song, J.S. (2007) Effects of High Energy Ball-Milling on the Sintering Behavior and Piezoelectric Properties of PZT-Based Ceramics. Ceramics International, 33, 1283-1286. http://dx.doi.org/10.1016/j.ceramint.2006.04.017

[7] Vuong, L.D. and Gio, P.D. (2013) Effect of $\mathrm{Li}_{2} \mathrm{CO}_{3}$ Addition on the Sintering Behavior and Physical Properties of PZT-PZN-Pmnn Ceramics. International Journal of Materials Science and Applications, 2, 89-93. http://dx.doi.org/10.11648/j.ijmsa.20130203.13

[8] Kim, J.M., Kim, J.S. and Cheon, C.I. (2011) Low-Temperature Sintering and Electrical Properties of PGO-Doped PNN-PZT Ceramics. Journal of Ceramic Processing Research, 12, 12-15.

[9] Yoo, J. and Lee, S. (2009) Piezoelectric and Dielectric Properties of Low Temperature Sintered $\mathrm{Pb}\left(\mathrm{Mn}_{1 / 3} \mathrm{Nb}_{2 / 3}\right)$ $0.02\left(\mathrm{Ni}_{1 / 3} \mathrm{Nb}_{2 / 3}\right) 0.12(\mathrm{ZrxTi1}-\mathrm{x}) 0.86 \mathrm{O}_{3}$ System Ceramics. Transactions on Electrical and Electronic Materials, 10, $121-$ 125.

[10] Chao, X., Yang, Z., Kang, C. and Chang, Y. (2008) Effects of $\mathrm{BiFeO}_{3}$ Addition on Electrical Properties and Temperature Stability of Low Temperature Sintered PZT-PFW-PMN Ceramics. Sensors and Actuators A: Physical, 141, 482488. http://dx.doi.org/10.1016/j.sna.2007.10.035

[11] Han, H.S., Park, E.C., Lee, J.S., Yoon, J.I. and Ahn, K.K. (2011) Low-Firing Pb(Zr,Ti)O $\mathrm{O}_{3}$-Based Multilayer Ceramic Actuators Using Ag Inner Electrode. Transactions on Electrical and Electronic Materials, 12, 249-252.

[12] Yoo, J., Lee, I., Paik, D.S. and Park, Y.W. (2009) Piezoelectric and Dielectric Properties of Low Temperature Sintering $\mathrm{Pb}\left(\mathrm{Mn}_{1 / 3} \mathrm{Nb}_{2 / 3}\right) \mathrm{O}_{3}-\mathrm{Pb}\left(\mathrm{Zn}_{1 / 3} \mathrm{Nb}_{2 / 3}\right) \mathrm{O}_{3}-\mathrm{Pb}\left(\mathrm{Zr}_{0.48} \mathrm{Ti}_{0.52}\right) \mathrm{O}_{3}$ Ceramics with Variation of Sintering Time. Journal of Electroceramics, 23, 519-523. http://dx.doi.org/10.1007/s10832-008-9524-0

[13] Yoon, S.J., Choi, J.W., Choi, J.Y., Wan, D., Li, Q. and Yang, Y. (2010) Influences of Donor Dopants on the Properties of PZT-PMS-PZN Piezoelectric Ceramics Sintered at Low Temperatures. Journal of the Korean Physical Society, 57, 863-867.

[14] Nam, C.H., Park, H.Y., Seo, I.T., Choi, J.H., Nahm, S. and Lee, H.G. (2011) Effect of CuO on the Sintering Temperature and Piezoelectric Properties of $\mathrm{MnO}_{2}$-Doped $0.75 \mathrm{~Pb}\left(\mathrm{Zr}_{0.47} \mathrm{Ti}_{0.53}\right) \mathrm{O}_{3}-0.25 \mathrm{~Pb}\left(\mathrm{Zn}_{1 / 3} \mathrm{Nb}_{2 / 3}\right) \mathrm{O}_{3}$ Ceramics. Journal of Alloys and Compounds, 509, 3686-3689. http://dx.doi.org/10.1016/j.jallcom.2010.12.163

[15] Fan, H. and Kim, H.E. (2002) Perovskite Stabilization and Electromechanical Properties of Polycrystalline Lead Zinc Niobate-Lead Zirconate Titanate. Journal of Applied Physics, 91, 317-322. http://dx.doi.org/10.1063/1.1421036

[16] Kim, M.S., Jeon, S., Jeong, S.J., Kim, I.S. and Song, J.S. (2008) Effect of CuO Additions on Microstructures and Electromechanical Properties of $0.4 \mathrm{~Pb}\left(\mathrm{Mg}_{1 / 3} \mathrm{Nb}_{2 / 3}\right) \mathrm{O}_{3}-0.25 \mathrm{PbZrO}_{3}-0.35 \mathrm{PbTiO}_{3}$ Ceramics. Electronic Materials Letters, 4 , 189-192.

[17] Kitaguchi, H., Takada, J., Oda, K. and Miura, Y. (1990) Equilibrium Phase Diagram for the System PbO-CaO-CuO. Journal of Materials Research, 5, 829-931. http://dx.doi.org/10.1557/JMR.1990.0929

[18] Kim, Y.H., Ryu, H., Cho, Y.K., Lee, H.J. and Nahm, S. (2013) TEM Observations on $0.65 \mathrm{~Pb}\left(\mathrm{Zr}_{0.42} \mathrm{Ti}_{0.58}\right) \mathrm{O}_{3^{-}}$ $0.35 \mathrm{~Pb}\left(\mathrm{Ni}_{0.33} \mathrm{Nb}_{0.67}\right) \mathrm{O}_{3}$ Ceramics with $\mathrm{CuO}$ Additive. Journal of the American Ceramic Society, 96, 312-317. http://dx.doi.org/10.1111/j.1551-2916.2012.05461.x

[19] Jian, H.L. (2013) Effect of CuO Addition on Structure and Electrical Properties of Low Temperature Sintered Quaternary Piezoelectric Ceramics. Bulletin of Materials Science, 36, 877-881.

[20] Nam, C.H., Park, H.Y., Seo, I.T., Choi, J.H., Joung, M.R., Nahm, S., et al. (2011) Low-Temperature Sintering and Piezoelectric Properties of $0.65 \mathrm{~Pb}\left(\mathrm{Zr}_{1-X} \mathrm{Ti}_{X}\right) \mathrm{O}_{3}-0.35 \mathrm{~Pb}\left(\mathrm{Ni}_{0.33} \mathrm{Nb}_{0.67}\right) \mathrm{O}_{3}$ Ceramics. Journal of the American Ceramic Society, 94, 3442-3448. http://dx.doi.org/10.1111/j.1551-2916.2011.04538.x

[21] Chao, X., Ma, D., Gu, R. and Yang, Z. (2010) Effects of CuO Addition on the Electrical Responses of the Low-Temperature Sintered $\mathrm{Pb}\left(\mathrm{Zr}_{0.52} \mathrm{Ti}_{0.48}\right) \mathrm{O}_{3}-\mathrm{Pb}\left(\mathrm{Mg}_{1 / 3} \mathrm{Nb}_{2 / 3}\right) \mathrm{O}_{3}-\mathrm{Pb}\left(\mathrm{Zn}_{1 / 3} \mathrm{Nb}_{2 / 3}\right) \mathrm{O}_{3}$ Ceramics. Journal of Alloys and Compounds, 491, 698-702. http://dx.doi.org/10.1016/j.jallcom.2009.11.048 
Scientific Research Publishing (SCIRP) is one of the largest Open Access journal publishers. It is currently publishing more than 200 open access, online, peer-reviewed journals covering a wide range of academic disciplines. SCIRP serves the worldwide academic communities and contributes to the progress and application of science with its publication.

Other selected journals from SCIRP are listed as below. Submit your manuscript to us via either submit@scirp.org or Online Submission Portal.
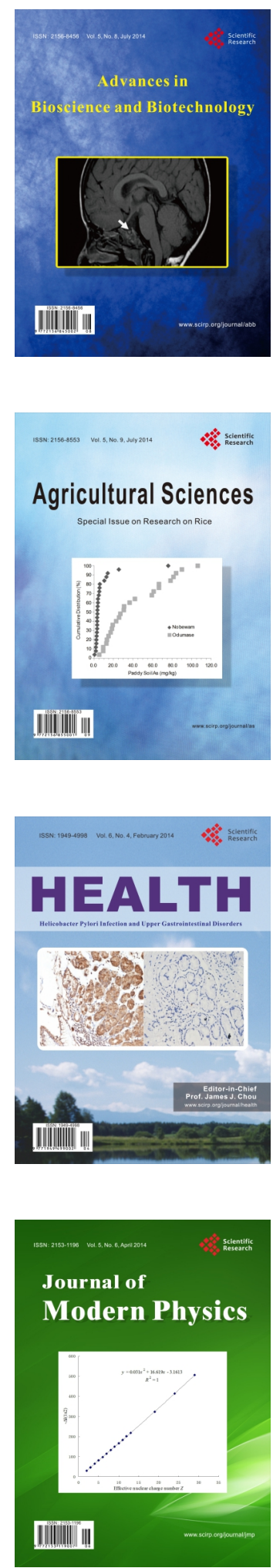
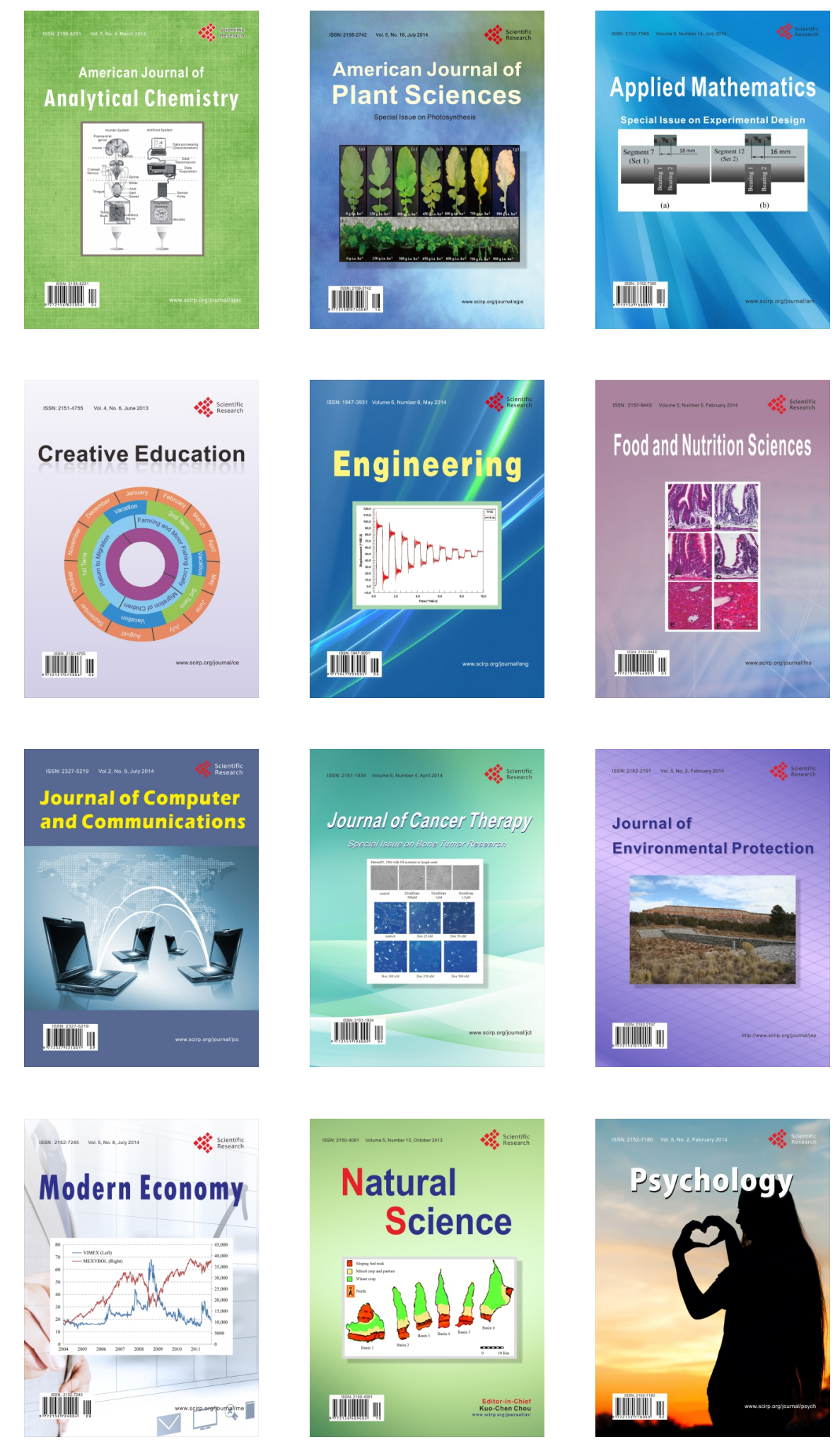